\title{
Prenatal Development of Gastrointestinal Function in the Pig and the Effects of Fetal Esophageal Obstruction
}

\author{
PER T. SANGILD, METTE SCHMIDT, JAN ELNIF, CHARLOTTE R. BJÖRNVAD, BJÖRN R. WESTRÖM, AND \\ RANDAL K. BUDDINGTON \\ Divisions of Nutrition and Reproduction, Royal Veterinary and Agricultural University, 13 Bulowsvej, \\ DK-1870 Frederiksberg C, Denmark [P.T.S., M.S., J.E., C.R.B.]; Department of Animal Physiology, \\ University of Lund, Helgonavägen 3B, S-223 62 Lund, Sweden [B.R.W.]; Department of Biological \\ Sciences, Mississippi State University, Mississippi State, MS 39762-5759, U.S.A. [R.K.B.]
}

\begin{abstract}
Maturation of the fetal gastrointestinal tract (GIT) is influenced by both luminal stimuli (e.g. swallowed fluid) and hormonal factors (e.g. endogenous cortisol release). The aims of the present study were 1) to investigate GIT growth and maturation during the last $20 \%$ of gestation in pigs (term $=114 \pm 2 \mathrm{~d}$ ), and 2) to investigate the effect of esophageal ligation, to prevent fetal swallowing, at $80 \%$ to $91 \%$ gestation. In normal fetuses, marked increases occurred during late gestation in body weight $(+95 \%)$, relative intestinal weight $\left(+79 \%, \mathrm{~g} \mathrm{~kg}^{-1}\right.$ body weight), activity of some digestive enzymes (1.5- to 10-fold), and absorption of glucose and intact proteins (3- to 6-fold). Fetuses with ligated esophagi had lowered body weight $(-20 \%)$, reduced intestinal weight $(-43 \%)$, aminopeptidase A activity $(-24 \%)$, and glucose absorption $(-27 \%)$, while lactase, sucrase, and dipeptidylpeptidase IV activities were increased $(+40-50 \%)$, compared with sham-operated fetuses (all $p<0.05$ ). Other parameters of GIT function remained unchanged by esophageal obstruction (absorption of amino acids and immunoglobulin, activity of chymosin,
\end{abstract}

\section{ABSTRACT}

amylase, trypsin, chymotrypsin, maltase, aminopeptidase $\mathrm{N}$ - all expressed per gram GIT tissue). Ligated fetuses had elevated cortisol levels, which is known to stimulate fetal GIT maturation. We conclude that the rapid development of GIT function in late gestation is diminished by esophageal obstruction, mainly due to slower GIT growth and not inhibition of normal functional development of enterocytes. (Pediatr Res 52: 416-424, 2002)
GIT, gastrointestinal tract
Abbreviations
$V_{\text {max }}$, maximum rate of nutrient uptake
$\mathbf{K}_{\mathbf{m}}$, nutrient affinity constant
ApN, aminopeptidase $\mathrm{N}$
ApA, aminopeptidase A
DPP IV, dipeptidyl peptidase IV
Gly, Sar, Glycine-Sarcosine
BIgG, bovine immunoglobulin $\mathrm{G}$

In many species, organ maturation is particularly rapid during the perinatal period. Development of the gastrointestinal tract (GIT) is stimulated by the transition from mainly parenteral nutrition before birth (via the placenta) to exclusively enteral nutrition after birth. Hence, enteral intake of nutrients in newborns elicits structural and functional GIT changes although the responses vary among species, source of nutrients, and specific GIT functions (1-4).

Enteral nutrient intake may also play a role before birth. During the last trimester human fetuses swallow fluid (up to $750 \mathrm{~mL} \mathrm{~d}^{-1}$ ) that contains dilute concentrations of protein, free

October 31, 2000; April 12, 2002.

Correspondence: Dr. Per Sangild, Division of Animal Nutrition, Royal Veterinary \& Agricultural University, 13 Bülowsvej, DK-1870 Frederiksberg C, Denmark; e-mail psa@kvl.dk

Supported by the Danish Agricultural and Veterinary Research Council.

DOI: 10.1203/01.PDR.0000025284.29777.E9 amino acids, and a variety of growth factors (5-7) derived from amniotic fluid and lung and nasal secretions. Although nutrients absorbed from these fluids are estimated to provide $10-$ $15 \%$ of fetal nitrogen requirements (8), and congenital intestinal atresia in humans is associated with fetal growthretardation $(9,10)$, it remains unclear whether the swallowed fluid is particularly important for the final phases of fetal GIT development. Evidence from humans and experimental animals (sheep, rabbits) suggests that esophageal obstruction may impair growth of the intestine, particularly if obstruction is complete and prevents luminal input in the final stage of gestation (9-17). The GIT matures relatively early in primates, particularly when compared with laboratory rodents (18). Hence, studies of GIT maturation in species with longer gestation, such as the pig or sheep, are likely to provide information that are more relevant to humans, even if differences still exist (19). 
In addition to the luminal influences, fetal GIT maturation is subject to endocrine regulation. In particular, the increase in fetal glucocorticoid secretion toward term is known to affect the functional development of the fetal liver, lungs, and GIT (20-23). Consistent with this, administration of glucocorticoids to preterm infants before and after birth reduces the risk of intestinal disease (24). In pigs and lambs, fetal cortisol secretion increases about 10-fold during the final $20 \%$ of gestation as a result of rapid adrenal gland growth and enhanced sensitivity of the adrenal cortex to stimulation by adrenocorticotropic hormone (ACTH) $(23,25,26)$. The natural surge in cortisol before birth and exogenous administration of glucocorticoids have been shown to reduce body growth rate in the perinatal period $(26,27)$. Possibly, Esophageal obstruction in late gestation may be associated with elevated cortisol release, acting in concert with the reduced enteral fluid intake to determine the outcome on GIT maturation and body growth.

The aims of this study were 1 ) to describe GIT growth and function during the final $20 \%$ of gestation in pigs, and 2) to study the influence of esophageal ligation on the pattern of GIT development. Ligated and sham-operated fetuses were delivered by caesarean section at a fetal age when the GIT maturation normally progresses very rapidly, and when pigs first become viable ex utero (2). Since the influences of enteral nutrients on the developing pig GIT vary widely among different ages, gut regions, and functions $(2,3,23)$, we measured a relatively large number of functional parameters (enzymes, nutrient transporters) throughout the GIT (stomach, pancreas, small intestine).

\section{MATERIALS AND METHODS}

Ontogeny study. A total of 36 untreated control pigs from 13 sows (Large White $\times$ Landrace) were used to describe organ development in late gestation. Fetal pigs were obtained by cesarean section on pregnant sows (thiopental anesthesia, 5-8 mg kg ${ }^{-1} \mathrm{~h}^{-1}$ ) at $80 \%$ of term (91 d gestation, $n=6$ from 1 sow), or at $91 \%$ of term (104 $\pm 1 \mathrm{~d}$ gestation, $n=18$ from 8 sows). Newborn unsuckled pigs were obtained just after term birth (114 $\pm 2 \mathrm{~d}, n=12$ from 4 sows).

Esophageal ligation study. A total of 18 fetuses from eight sows were used to study the effect of esophageal ligation during the period from $80 \%$ to $91 \%$ gestation. At $91 \pm 1 \mathrm{~d}$ gestation (term $=114 \pm 2 \mathrm{~d}$ ), the eight pregnant sows were sedated with azaperone $\left(0.05 \mathrm{~mL} \mathrm{~kg}^{-1}\right.$, i.m., Janssen, Beerse, Belgium), and anesthesia was induced with thiopental sodium (5 mg kg ${ }^{-1}$, i.v., Abbott, North Chicago, IL, U.S.A.) and maintained with isoflurane ( $1 \%$ to $2 \%$ in oxygen, Abbott, North Chicago, IL, U.S.A.) using an endotracheal tube. The sows were covered with insulating blankets to prevent an anesthesia-induced hypothermia and care was taken to maintain aseptic conditions around a ventral flank incision. After exposure of the uterus, 3 fetuses were chosen randomly for fetal surgery. For each fetus, a small incision was made in a relatively nonvascular area of the uterus and the fetal allantoic and amniotic membranes were then carefully anchored onto the uterine wall incision. The head of each fetus was exteriorized during fetal surgery. Dehydration and cooling were prevented by covering the fetal head with a sterile, wet heating pad. A ventral midline incision was made in the neck to expose the fetal esophagus, which was then ligated with cotton thread $(n$ $=10$ ). In sham-operated fetuses, the fetal esophagus was exposed, but not ligated $(n=8)$. After operation, the fetal skin incision and membranes were closed, and antibiotics $(50 \mathrm{mg}$ Ampicillin, Yamanonchi Europe, Leiderdorp, The Netherlands) added to the amniotic cavity before closure of the uterine incision. After fetal surgery, antibiotics were given to the sow for $4 \mathrm{~d}\left(20 \mathrm{~mL} \mathrm{~d}^{-1}\right.$, i.m., Streptocillin, Boeringer Ingelheim, Copenhagen, Denmark) and progesterone was administered $\left(50 \mathrm{mg} \mathrm{d}^{-1}, \mathrm{i} . \mathrm{m}\right.$.) as a precaution against preterm labor. In one sow only two fetuses were operated, and of the 23 operated fetuses from 8 sows, 3 sham-operated and 2 ligated fetuses died before cesarean delivery at 103-107 d gestation (mean $104 \pm 1 \mathrm{~d}$ gestation). All procedures were approved by the National Committee on Animal Experimentation, Denmark.

Blood analyses and tissue collection. Each pig was sampled from the umbilical artery with an ice-chilled heparinized syringe before being killed for tissue collection (sodium pentobarbitone, $200 \mathrm{mg} \mathrm{kg}^{-1}$, i.v.). Blood $\mathrm{pH}, \mathrm{Po}_{2}, \mathrm{PCO}_{2}, \mathrm{Hb}$, and concentrations of $\mathrm{Na}^{+}, \mathrm{Cl}^{-}, \mathrm{K}^{+}, \mathrm{Ca}^{+}$and glucose were measured using a hemoximeter (Radiometer, Copenhagen, Denmark) and a blood gas and electrolyte analyzer (NOVA Biomedical, Waltham, MA, U.S.A.). Cortisol concentrations in plasma were determined by ELISA (Biomar Diagnostics, Marburg, Germany). After euthanasia, body weight was recorded and the small intestine, from the pyloric sphincter to the ileo-colonic junction, was rapidly removed by cutting along the mesenteric border. Segments were removed from the proximal, middle, and distal regions of the small intestine $(17 \%, 50 \%$, and $83 \%$ from the pyloric sphincter, respectively) for measuring intestinal dimensions and nutrient absorption by the "everted sleeve technique" (28). The stomach, pancreas, lungs, liver, spleen, heart, adrenals, and kidneys were collected and weighed (within 5-10 min of death). The volume and $\mathrm{pH}$ of stomach fluid was recorded. Additional pieces of the small intestine (proximal, middle, distal), pancreas, and fundic stomach were frozen at $-80^{\circ} \mathrm{C}$ until later biochemical analyses. Intestinal tissues used for histologic examinations were fixed in Carnoy's fluid for 6-8 h, transferred to $70 \%$ ethanol, embedded in paraffin, sectioned $(5 \mu \mathrm{m})$, and stained with eosin and hematoxylin. Only a subset of the intestinal samples was examined ( $n=3$ for each treatment).

Gastrointestinal enzyme levels. Frozen stomach tissue was homogenized in phosphate buffer $\left(0.05 \mathrm{M}, \mathrm{pH} 6.0,2 \mathrm{~min}, 0^{\circ} \mathrm{C}\right)$, centrifuged, and the concentrations of 4 proteases (chymosin, pepsin A, pepsin B, pepsin C) determined in the supernatant by quantitative immunoelectrophoresis against mono-specific antisera (29). The results were expressed as mg enzyme per $g$ tissue.

Frozen pancreas tissue was homogenized in Tris- $\mathrm{HCl}$ buffer (100 mM containing $20 \mathrm{mM} \mathrm{CaCl}_{2}, \mathrm{pH} \mathrm{7.9,2} \min , 0^{\circ} \mathrm{C}$ ), centrifuged $\left(20000 \times \mathrm{g}, 45 \mathrm{~min}, 4^{\circ} \mathrm{C}\right)$, and the supernatant used for analysis of hydrolase activity. Ethylidene-pnitrophenyl, D-maltoheptaside was used as a substrate for amylase and the liberated glucose determined spectrophoto- 
metrically at $405 \mathrm{~nm}$ (577-50P, Sigma Chemical Co., St. Louis, MO, U.S.A.). Likewise, benzoyl-arginine-p-nitroanilide was used as the substrate for trypsin after activation of the trypsinogen with enterokinase (B 4875 and E 0632, Sigma Chemical Co.), and chymotrypsin was measured using SuccAAPF-p-nitroanilide (S 7388, Sigma Chemical Co.) as a substrate. A hydrolytic rate of one $\mu \mathrm{mol}$ of substrate released per $\min$ at $37^{\circ} \mathrm{C}$ represents one unit (U) of enzyme activity.

Frozen intestinal tissue was homogenized in $1.0 \%$ Triton $\mathrm{X}-100$ and the homogenates assayed for disaccharidase and peptidase activities (23). Sucrose (0.01 M; no. 194018, ICN, Aurora, OH, U.S.A.) and lactose (0.12 M; L-3625, Sigma Chemical Co. dissolved in sodium maleate buffer $(50 \mathrm{mM}, \mathrm{pH}$ 6.0) were used as substrates for sucrase-isomaltase (EC 3.2.1.48-10) and lactase-phloridzin hydrolase (EC 3.2.1.2362), respectively. Maltose (0.0112 M; L-5885, Sigma Chemical Co.) was used to measure maltase activity, which represents the combined activity of maltase-glucoamylase (EC 3.2.1.20) and sucrase-isomaltase. Aminopeptidase N (ApN, EC 3.4.11.2), dipeptidyl peptidase IV (DPP IV, EC 3.4.14.5) and aminopeptidase A (ApA, EC 3.4.11.7) activities were measured using three peptidase-specific substrate solutions: $10 \mathrm{mM}$ L-alanine-4-nitroanilide (Merck, Darmstadt, Germany) in 50 $\mathrm{mM}$ Tris-HCl, pH 7.3, 15 mM glycyl-L-proline-4-nitro-anilide (Bachem, Bubendorf, Switzerland) in $50 \mathrm{mM}$ Tris- $\mathrm{HCl}, \mathrm{pH}$ 8.0, and $10 \mathrm{mM} \alpha$-L-glutamic acid 4-nitroanilide (synthesized at the Institute of Protein Chemistry, Hørsholm, Denmark) in $50 \mathrm{mM}$ Tris-HCl, $\mathrm{pH}$ 8.0, respectively.

In vitro intestinal nutrient uptake. The segments of proximal, middle, and distal small intestine were everted and $1 \mathrm{~cm}$ sleeves were mounted on steel rods and incubated for $2.0 \mathrm{~min}$ in mammalian Ringers solutions $\left(36^{\circ} \mathrm{C}\right)$ containing either glucose, one of three amino acids (leucine, lysine, proline) or a dipeptide (glycyl-sarcosine, Gly-Sar, each at $50 \mathrm{mmol} \mathrm{L}^{-1}$ ), as previously described (28). Accumulation of nutrients by the tissues was quantified by adding trace levels of ${ }^{14} \mathrm{C}$-D glucose (ICN Biomedicals, Irvine, CA, U.S.A.), ${ }^{3} \mathrm{H}-\mathrm{L}$ amino acids (New England Nuclear, Boston, MA, U.S.A.), and ${ }^{3} \mathrm{H}-\mathrm{Gly}-\mathrm{Sar}$ (Amersham, Canada). The amino acids studied (leucine, lysine, proline) are substrates for three different carrier systems (neutral, basic, and imino). Gly-Sar was selected because it is carried by the peptide transporter and the peptide bond is resistant to hydrolysis by the apical membrane peptidases. Tracer concentrations of ${ }^{3} \mathrm{H}-\mathrm{L}$-glucose (ICN Biomedicals) were added to the D-glucose solutions to correct for glucose associated with adherent fluid and passively absorbed, and tracer ${ }^{14} \mathrm{C}$-labeled polyethylene glycol (MW 4,000; New England Nuclear, Boston, MA, U.S.A.) was added to the amino acid and dipeptide solutions to account for nutrient in adherent fluid. Calculated rates (30) for glucose represent carriermediated absorption only, whereas amino acid and dipeptide uptakes include both the carrier-mediated and carrierindependent pathways of absorption. Values were expressed as $\mu \mathrm{mol}$ absorbed $\min ^{-1} \mathrm{~g}$ tissue ${ }^{-1}$.

The regional distribution of absorption was defined by incubating tissues from each of the three regions in $50 \mathrm{mmol} \mathrm{L}^{-1}$ nutrient solutions. The kinetics of absorption (affinity constant, $\mathrm{K}_{\mathrm{m}}$, and maximum rates of carrier-mediated absorption, $V_{\max }$ ) were determined by measuring rates of absorption as functions of nutrient concentration using proximal intestine for glucose (tracer alone and with $0.5,5,25$, and $50 \mathrm{mmol} \mathrm{L}^{-1}$ unlabeled nutrient) and mid intestine for the amino acids and dipeptide (tracer alone and with $0.25,2.5,25$, and $50 \mathrm{mmol} \mathrm{L}^{-1}$ unlabeled nutrient). In addition, accumulation of tracer by the tissues in the absence of unlabeled nutrient was divided by accumulation in the presence of $50 \mathrm{mmol} \mathrm{L}{ }^{-1}$ unlabeled nutrient (accumulation ratio). Accumulation ratios greater than 1.0 indicate that absorption includes a saturable carrier, while ratios similar to 1.0 indicate that the transporters are present in very low densities and absorption is largely by simple diffusion (28).

The ability of the small intestine to absorb protein macromolecules by endocytosis was also assessed in vitro using a modification of the approach used to measure nutrient absorption. Everted sleeves of proximal, middle, and distal small intestine were incubated at $36^{\circ} \mathrm{C}$ in a solution of porcine colostrum whey containing 2 marker proteins, BSA (BSA, A-4503, Sigma Chemical Co.; $5.0 \mathrm{~g} \mathrm{~L}^{-1}$ ), and bovine $\operatorname{IgG}$ (BIgG, G-5009, Sigma Chemical Co.; $5.0 \mathrm{~g} \mathrm{~L}^{-1}$ ). Porcine colostrum whey facilitates maximal protein absorptive capacity in newborn pigs (4). After an incubation period of $5 \mathrm{~min}$ (chosen based on preliminary analyses of protein uptake tested over a 0-30 min incubation period), the tissues were rinsed (Ringers solution, $30 \mathrm{~s}, 36^{\circ} \mathrm{C}$ ) to remove $\mathrm{BSA}$ or $\mathrm{BIgG}$ not associated with surface receptors or internalized. Accumulation of BSA and BIgG was quantified in homogenates of intestinal tissue (100 mg tissue per $\mathrm{mL}$ PBS buffer, $\mathrm{pH}$ 7.6) using immunoelectrophoresis and mono-specific antisera (4). Results were expressed as incorporated protein $(\mu \mathrm{g}) \mathrm{g}$ tissue $^{-1}$.

Data analysis. Values presented in tables and figures are means (or LSmeans) and standard errors. The main effect of age $(80,91,100 \%$ gestation), intestinal region (proximal, middle, distal), or treatment (ligated, sham-operation) was determined by analysis of variance (31). When a significant age effect was detected in the ontogeny study, differences between two means were identified by Duncan's Multiple Range test. Statistical comparisons of LSmeans values were used to detect treatment differences in the esophageal ligation study. The univariate procedure (31) was used to determine whether accumulation ratios differed from 1.0. Correlations between cortisol values (or relative weight of adrenal glands) and other measured parameters were tested by linear regression analysis (31). A probability value of 0.05 was used as the critical level of significance for all statistical evaluations.

\section{RESULTS}

Organ weights. Ontogeny study. During the last $20 \%$ of gestation, body weight doubled $(+95 \%)$ and there was a significant effect of gestational age on the weight (expressed relative to body weight) of all organs shown in Table 1 ( $p<$ $0.05)$, except stomach and kidneys. Increases in relative weight were present for liver $(+24 \%)$, heart $(+29 \%)$, adrenals $(+93 \%)$, and small intestine $(+79 \%)$, while decreases occurred for lungs $(-48 \%)$, spleen $(-46 \%)$, and pancreas $(-27 \%)$. During this period, the intestine did not grow in 
Table 1. Organ weights and intestinal dimensions in control fetal pigs removed by caesarean section at 80 or $91 \%$ gestation or born spontaneously at term $(100 \%)$ *

\begin{tabular}{lccc}
\hline \multicolumn{1}{c}{ Fetal age $(\%$ of gestation) } & 80 & 91 & 100 \\
\hline No. of animals & 6 & $1183 \pm 93^{\mathrm{a}}$ & 12 \\
Body weight $(\mathrm{g})$ & $658 \pm 67^{\mathrm{b}}$ & $29.3 \pm 1.1^{\mathrm{a}}$ & $1282 \pm 93^{\mathrm{a}}$ \\
Lung weight $\left(\mathrm{g} \mathrm{kg}^{-1}\right)$ & $29.6 \pm 1.8^{\mathrm{a}}$ & $25.1 \pm 1.0^{\mathrm{b}}$ & $15.3 \pm 0.9^{\mathrm{b}}$ \\
Liver weight $\left(\mathrm{g} \mathrm{kg}^{-1}\right)$ & $24.4 \pm 1.1^{\mathrm{b}}$ & $1.44 \pm 0.08^{\mathrm{b}}$ & $30.2 \pm 0.8^{\mathrm{a}}$ \\
Spleen weight $\left(\mathrm{g} \mathrm{kg}^{-1}\right)$ & $2.07 \pm 0.10^{\mathrm{a}}$ & $6.84 \pm 0.15^{\mathrm{b}}$ & $1.11 \pm 0.06^{\mathrm{c}}$ \\
Heart weight $\left(\mathrm{g} \mathrm{kg}^{-1}\right)$ & $5.85 \pm 0.18^{\mathrm{c}}$ & $8.00 \pm 0.43^{\mathrm{a}}$ & $7.56 \pm 0.29^{\mathrm{a}}$ \\
Adrenal weight $\left(\mathrm{mg} \mathrm{kg}^{-1}\right)$ & $103 \pm 11^{\mathrm{b}}$ & $4.11 \pm 0.08^{\mathrm{a}}$ & $199 \pm 7^{\mathrm{a}}$ \\
Kidney weight $\left(\mathrm{g} \mathrm{kg}^{-1}\right)$ & $4.86 \pm 0.38^{\mathrm{a}}$ & $0.96 \pm 0.04^{\mathrm{b}}$ & $7.75 \pm 0.25^{\mathrm{a}}$ \\
Stomach weight $\left(\mathrm{g} \mathrm{kg}^{-1}\right)$ & $1.10 \pm 0.05^{\mathrm{a}}$ & $17.5 \pm 1.2^{\mathrm{b}}$ & $4.11 \pm 0.13^{\mathrm{a}}$ \\
Pancreas weight $\left(\mathrm{g} \mathrm{kg}^{-1}\right)$ & $14.5 \pm 0.5^{\mathrm{c}}$ & $258 \pm 10$ & $0.80 \pm 0.03^{\mathrm{c}}$ \\
Intestinal weight $\left(\mathrm{g} \mathrm{kg}^{-1}\right)$ & $319 \pm 29$ & $7.2 \pm 0.2^{\mathrm{b}}$ & $26.0 \pm 1.6^{\mathrm{a}}$ \\
Intestinal length $\left(\mathrm{cm} \mathrm{kg}^{-1}\right)$ & $6.3 \pm 0.3^{\mathrm{c}}$ & $66.1 \pm 1.5^{\mathrm{b}}$ & $270 \pm 11$ \\
Intestinal circumference $(\mathrm{mm}) \dagger$ & $52.3 \pm 1.8^{\mathrm{c}}$ & $7.8 \pm 0.2^{\mathrm{a}}$ \\
Proportion of mucosa $(\%)+$ & & $71.9 \pm 1.2^{\mathrm{a}}$ \\
\hline
\end{tabular}

* Means not sharing a common superscript letter are significantly different $(p<0.05$, Duncans Multiple Range test).

$\dagger$ The mean intestinal circumference across 3 intestinal regions.

$\ddagger$ Proportion of mucosal dry weight per total intestinal dry weight, mean values across 3 intestinal regions.

relative length, but showed increased circumference $(+40 \%)$ and percentage of mucosa $(+37 \%)$. As a result, the total wet weight of intestinal mucosa per $\mathrm{kg}$ body weight rose by $+146 \%$.

Esophageal ligation study. When the operated fetuses were delivered at $91 \%$ gestation, mean body weight for the 10 ligated fetuses $(0.868 \pm 0.076 \mathrm{~kg})$ was significantly lowered $(p$ $<0.05$, Fig. 1) compared with the 8 sham-operated fetuses $(1.102 \pm 0.052 \mathrm{~kg})$. The ligated fetuses showed variable degrees of muscle wasting (visible skeletal elements) and appeared emaciated compared with sham-operated fetuses.

At cesarean delivery, ligated fetuses had a reduced total intestinal weight $(-43 \%$, Fig. 1) and intestinal to body weight ratio $(-26 \%, p<0.05)$, compared with sham-operated pigs. The reduction in weight was associated with a decreased intestinal circumference $(6.3 \pm 0.3$ versus $7.9 \pm 0.5 \mathrm{~mm}, p<$ 0.05 ), while intestinal length and proportion of mucosa were unchanged (data not shown). Histologic examination of a subset of the tissues ( $n=3$ for each treatment) did not reveal any differences between ligated and sham-operated fetuses. The relative weights of all other organs measured (see Table 1) did not differ between ligated and sham fetuses, although relative weights of adrenal glands and kidneys tended to be

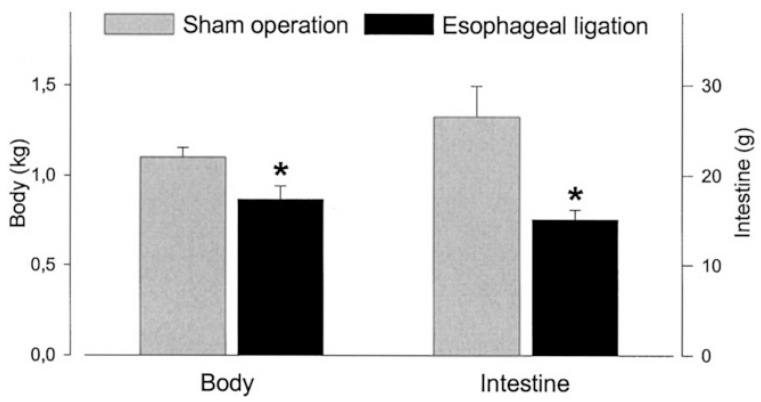

Figure 1. The effects of fetal esophageal obstruction on body weight and small intestinal weight. Fetuses, in which the esophagus had been previously ligated $(n=10)$, were removed together with sham-operated fetuses $(n=8)$ from pregnant sows at $91 \%$ gestation $(\sim 104 \mathrm{~d}$ fetal age, means \pm SEM, $* p<$ 0.05 for ligated $v s$ sham fetuses). elevated in ligated pigs $\left(198 \pm 21\right.$ versus $142 \pm 20 \mathrm{mg} \mathrm{kg}^{-1}$ and $10.7 \pm 0.4$ versus $9.3 \pm 0.5$, both $p=0.08$ ).

Stomach and exocrine pancreas function. Ontogeny study. During the last $20 \%$ of gestation, stomach chymosin concentrations increased 5-fold and stomach fluid $\mathrm{pH}$ decreased from neutral values in fetal pigs to $\mathrm{pH} 2-3$ at term (Table 2). Only trace amounts of pepsinogen A, B, and C were found in fetal and newborn pigs and these did not allow for any quantitative comparisons. Pancreatic hydrolase concentrations increased markedly during late gestation, particularly that of amylase (10-fold increase, Table 2).

Esophageal ligation study. Stomach chymosin and pancreatic enzyme concentrations (Fig. 2) did not differ between the ligated and sham-operated pigs. The same was true for stomach acidity (data not shown), but the pooled $\mathrm{pH}$ value from all operated pigs ( $\mathrm{pH} 4.4 \pm 0.6)$ was lower $(p<0.05)$ than in unoperated pigs removed at a similar age ( $\mathrm{pH} 6.6 \pm 0.4)$.

Intestinal enzyme activities. Ontogeny study. Significant increases occurred in the tissue-specific lactase, sucrase, and ApN activities during the last $20 \%$ of gestation, while maltase, DPP IV, and ApA activities were similar at $80 \%$ gestation and at term (Table 3). The total intestinal hydrolytic capacity, calculated as the average tissue-specific enzyme activity across the 3 intestinal regions multiplied with total intestinal weight, increased with fetal age for all six enzymes, most for lactase (3-fold increase) and least for DPP IV (1.5-fold increase).

Esophageal ligation study. Analyzed across all three intestinal regions, ligated pigs showed increased lactase, sucrase, and DPPIV activities while ApA activity was decreased, relative to sham fetuses (Fig. $3 A$ ). Also ApN activities tended to be increased in ligated fetuses $(p=0.09)$. There was a significant effect of intestinal region on all enzyme activities $(p<0.05$, analysis of variance) and the above ligation effects on enzyme activities were most pronounced in the proximal small intestine (about 2-fold differences between treatments).

Intestinal glucose uptake. Ontogeny study. Rates of glucose uptake across the 3 intestinal regions increased 4-fold during the last $20 \%$ of gestation (Table 3 ) and this increase was most 
Table 2. Stomach and pancreas function in control fetal pigs removed by caesarean section at 80 or $91 \%$ gestation or born spontaneously at term $(100 \%) *$

\begin{tabular}{lccc}
\hline \multicolumn{1}{c}{ Fetal age $(\%$ of gestation) } & 80 & 91 & 100 \\
\hline Stomach fluid acidity $(\mathrm{pH})$ & $7.73 \pm 0.24^{\mathrm{a}}$ & $6.56 \pm 0.39^{\mathrm{b}}$ & $2.39 \pm 0.26^{\mathrm{c}}$ \\
Stomach chymosin $\left(\mathrm{mg} \mathrm{g}^{-1}\right)$ & $0.95 \pm 0.10^{\mathrm{c}}$ & $2.87 \pm 0.58^{\mathrm{b}}$ & $5.14 \pm 0.77^{\mathrm{a}}$ \\
Pancreas amylase $\left(\mathrm{U} \mathrm{g}^{-1}\right)$ & $2.4 \pm 0.7^{\mathrm{c}}$ & $11.8 \pm 1.4^{\mathrm{b}}$ & $25.6 \pm 5.1^{\mathrm{a}}$ \\
Pancreas chymotrypsin $\left(\mathrm{U} \mathrm{g}^{-1}\right)$ & $997 \pm 71^{\mathrm{b}}$ & $1460 \pm 145^{\mathrm{a}}$ & $1517 \pm 161^{\mathrm{a}}$ \\
Pancreas trypsin $\left(\mathrm{U} \mathrm{g}^{-1}\right)$ & $1.11 \pm 0.14^{\mathrm{c}}$ & $1.83 \pm 0.25^{\mathrm{b}}$ & $3.27 \pm 0.51^{\mathrm{a}}$ \\
\hline
\end{tabular}

* Means not sharing a common superscript letter are significantly different $(p<0.05$, Duncans Multiple Range test).

pronounced in the proximal and middle intestine (5-fold increases), where uptake was also higher (2- to 3 -fold) than in the distal region. The combination of the 4-fold increase in tissuespecific uptake and growth of the intestine resulted in a 7-fold increase in total glucose uptake capacity per kg body weight. Across the ages, there was a mean glucose tracer accumulation ratio of $42 \pm 7$ and this verified the presence of a saturable, carrier-mediated mechanism for glucose uptake in both the proximal and distal regions of prenatal pigs. The highest ratios were found for fetal pigs at $80 \%$ gestation $(87 \pm 18)$. Maximum rates of glucose transport ( $V_{\max }$ values) increased gradually until term $\left(1.11 \pm 0.10\right.$ to $7.13 \pm 0.41 \mathrm{nmol} \mathrm{min}{ }^{-1}$ $\left.\mathrm{mg}^{-1}\right)$ while apparent affinity constants $\left(\mathrm{K}_{\mathrm{m}}\right.$ values) were similar at $80 \%$ of gestation and at term $\left(0.4-0.5 \mathrm{mmol} \mathrm{L}^{-1}\right)$.

Esophageal ligation study. Compared with sham operation, esophageal ligation was associated with a reduced tissuespecific uptake of glucose (Fig. 3B) and a reduced tracer accumulation ratio $(12.4 \pm 2.5$ versus $26.8 \pm 4.9, p<0.05)$, but there was no effect on kinetic constants.

Intestinal amino acid, dipeptide, and intact protein uptake. Ontogeny study. Among the 4 amino acids, only leucine showed a significant increase in uptake with age $(+25 \%, p<$ 0.05 , Table 3$)$, most clearly in the proximal intestine $(+60 \%)$. Because of intestinal growth (Table 1), uptake capacities normalized to body weight increased about 2-fold for all 4 amino acids. Amino acid absorption as a function of amino acid concentration showed a curvilinear response indicating that both a carrier-mediated pathway and an apparent diffusion component were present. Accumulation ratios exceeded 1.0 for all three amino acids at all ages, with the highest values for leucine $(12.6 \pm 1.9)$ and lysine $(6.0 \pm 1.0)$ and the lowest value for proline $(1.9 \pm 0.2)$. For leucine, the $V_{\max }$ value increased between $80 \%$ of gestation and term $(0.5 \pm 0.2$ to 2.2 $\pm 0.4 \mathrm{mmol} \mathrm{g} \mathrm{g}^{-1} \mathrm{~min}^{-1}$ ) while apparent affinity constants remained constant (mean of $0.8 \mathrm{mmol} \mathrm{L}^{-1}$ ). For lysine and proline, $V_{\max }$ values also increased and were similar to those for leucine $\left(0.2-3.6 \mathrm{mmol} \mathrm{g}^{-1} \mathrm{~min}^{-1}\right)$ but apparent affinities were lower $\left(\mathrm{K}_{\mathrm{m}}\right.$ values of $\left.6-37 \mathrm{mmol} \mathrm{L}{ }^{-1}\right)$.

Uptake of the dipeptide, Gly-Sar, increased significantly from $80 \%$ gestation to term $\left(1.95 \pm 0.17\right.$ to $2.84 \mathrm{mmol} \mathrm{g}^{-1}$ $\left.\min ^{-1}, p<0.05\right)$ although the average uptake values across the 3 regions showed no significant change (Table 3). The Gly-Sar accumulation ratios exceeded 1.0 at all three fetal ages and increased from $2.7 \pm 0.2$ at $80 \%$ gestation to $4.3 \pm 0.2$ at term. The $V_{\max }$ value for Gly-Sar absorption did not change with gestational age and averaged $1.7 \mathrm{nmol} \mathrm{mg}{ }^{-1} \min ^{-1}$, while apparent affinity constants increased (from 9 to $18 \mathrm{mmol} \mathrm{L}^{-1}$ ). The 2 marker proteins, BSA, and BIgG, showed large increases in tissue-specific uptake from $80 \%$ gestation to term (3- to 6-fold increases, Table 3), and there was no regional preference in the uptake levels as measured in vitro.

Esophageal ligation study. Apart from a tendency to a reduced proline uptake $(p=0.09)$, uptake of the 4 amino acids, the dipeptide and the 2 marker proteins did not differ between ligated and sham-operated fetuses (Fig. 3B). Likewise, no differences were observed between treatments in the kinetic constants for amino acid and dipeptide uptake.

Plasma cortisol and blood chemistry. Ontogeny study. Plasma cortisol increased 6-fold in late gestation ( $25 \pm 5$, $46 \pm$ 4 , and $156 \pm 23 \mathrm{ng} \mathrm{mL}^{-1}$ for the 3 age groups). Across all ages

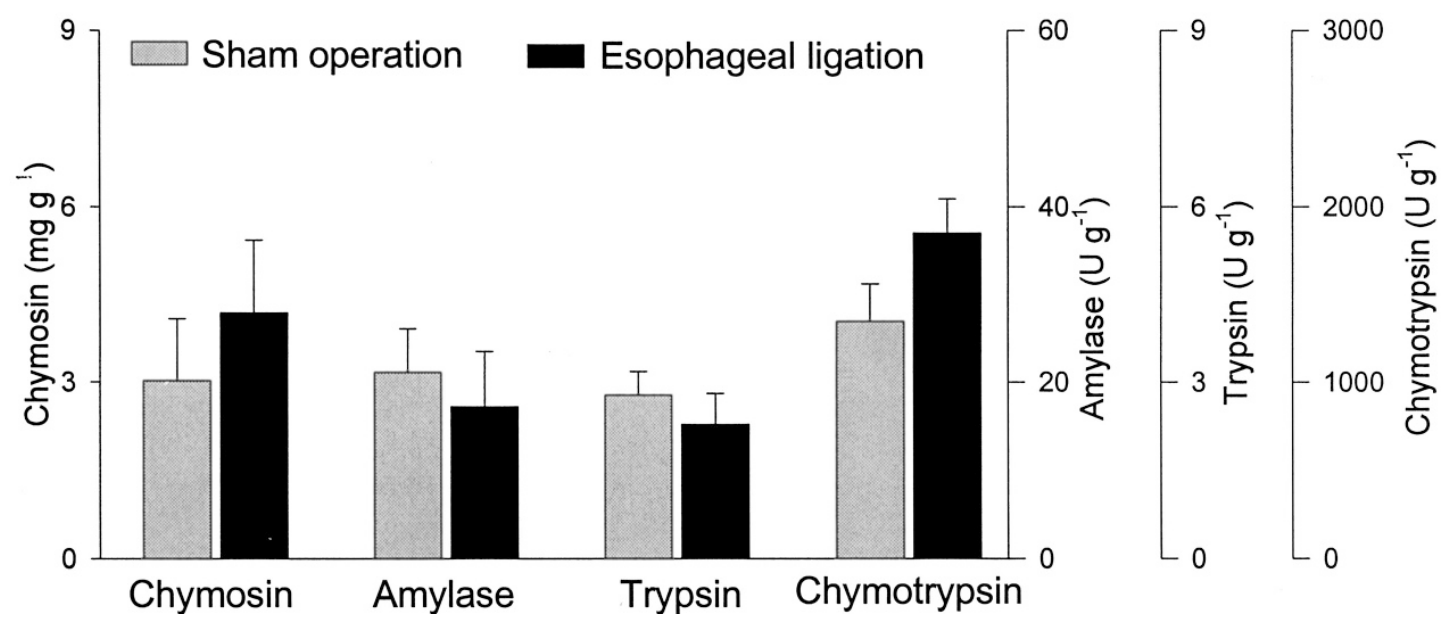

Figure 2. The effects of fetal esophageal obstruction on enzyme contents (means \pm SEM) in the stomach (chymosin) and pancreas (amylase, trypsin, chymotrypsin). See also legend to Fig. 1. 


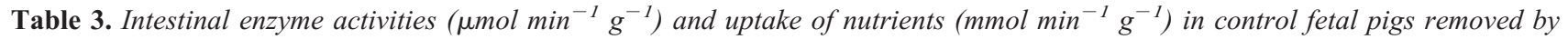
caesarean section at 80 or $91 \%$ gestation or born spontaneously at term (100\%)*

\begin{tabular}{lccc}
\hline Fetal age (\% of gestation) & 80 & 91 & 100 \\
\hline Intestinal enzyme activities & & & \\
Lactase & $28.6 \pm 2.4^{\mathrm{b}}$ & $50.3 \pm 3.2^{\mathrm{a}}$ & $46.6 \pm 4.8^{\mathrm{a}}$ \\
Maltase & $1.88 \pm 0.27^{\mathrm{a}}$ & $1.56 \pm 0.13^{\mathrm{a}}$ & $1.68 \pm 0.07^{\mathrm{a}}$ \\
Sucrase & $0.26 \pm 0.02^{\mathrm{b}}$ & $8.22 \pm 0.01^{\mathrm{b}}$ & $0.35 \pm 0.03^{\mathrm{a}}$ \\
Aminopeptidase N & $5.98 \pm 0.84^{\mathrm{b}}$ & $2.12 \pm 0.14^{\mathrm{b}}$ & $9.22 \pm 0.76^{\mathrm{a}}$ \\
Aminopeptidase A & $3.64 \pm 0.67^{\mathrm{a}}$ & $3.95 \pm 0.24^{\mathrm{a}}$ & $2.61 \pm 0.29^{\mathrm{ab}}$ \\
Dipeptidyl Peptidase IV & $3.94 \pm 0.67^{\mathrm{ab}}$ & & $2.71 \pm 0.28^{\mathrm{b}}$ \\
Intestinal nutrient uptake & & $2.49 \pm 0.21^{\mathrm{b}}$ & $4.88 \pm 0.27^{\mathrm{a}}$ \\
Glucose & $1.16 \pm 0.13^{\mathrm{c}}$ & $2.38 \pm 0.15^{\mathrm{b}}$ & $2.87 \pm 0.16^{\mathrm{a}}$ \\
Leucine & $2.31 \pm 0.16^{\mathrm{b}}$ & $2.31 \pm 0.21^{\mathrm{a}}$ & $2.09 \pm 0.17^{\mathrm{a}}$ \\
Lysine & $2.43 \pm 0.21^{\mathrm{a}}$ & $3.71 \pm 0.30^{\mathrm{a}}$ & $3.42 \pm 0.14^{\mathrm{a}}$ \\
Proline & $3.31 \pm 0.26^{\mathrm{a}}$ & $2.30 \pm 0.47^{\mathrm{a}}$ & $2.30 \pm 0.10^{\mathrm{a}}$ \\
Glycine-Sarcosine & $2.11 \pm 0.15^{\mathrm{a}}$ & $219 \pm 25^{\mathrm{b}}$ & $811 \pm 46^{\mathrm{a}}$ \\
Bovine serum albumin & $126 \pm 8^{\mathrm{c}}$ & $232 \pm 28^{\mathrm{b}}$ & $348 \pm 26^{\mathrm{a}}$ \\
Bovine immunoglobulin G & $129 \pm 8^{\mathrm{c}}$ & \\
\hline
\end{tabular}

* The values represent the mean tissue-specific enzyme activities and uptakes of nutrients across 3 intestinal regions. Means not sharing a common superscript letter are significantly different $(p<0.05$, Duncans Multiple Range test).

and treatments it was highly correlated with relative adrenal gland weight $(\mathrm{r}=0.70, p<0.0001)$.

Esophageal ligation study. The blood chemistry values did not differ between ligated and sham-operated fetuses, and were within the range reported previously for chronically catheterized pig fetuses $(32,33)$. The pooled blood chemistry values for all operated pigs (ligated + shams) did not differ from those in unoperated pigs at the same age, except for higher hematocrit and $\mathrm{Hb}$ values $(41 \pm 6$ versus $28 \pm 1 \%$ and $14.3 \pm 1.3$ versus $9.3 \pm 0.3 \mathrm{mg} \mathrm{dL}^{-1}$, both $\left.p<0.05\right)$. The ligated fetuses had significantly elevated cortisol levels compared with shamoperated fetuses $\left(102 \pm 19\right.$ versus $\left.58 \pm 9 \mathrm{ng} \mathrm{mL}^{-1}\right)$.

Correlation between adrenal gland function and other parameters. Analyzed across all the fetuses delivered at $91 \%$ gestation with normal access to swallowed fluid (unoperated control fetuses and sham-operated fetuses, $n=26$ ), relative adrenal gland weight values correlated negatively with body weight $(\mathrm{r}=-0.48, p<0.001)$ and positively with relative kidney weight $(\mathrm{r}=0.50, p<0.01)$. Relative adrenal gland weight was not correlated with any of the other parameters listed in Table 1. For the parameters listed in Tables 2 and 3, relative adrenal gland weight correlated positively with stomach chymosin concentrations $(\mathrm{r}=0.82, p<0.0001)$, activity of intestinal maltase $(\mathrm{r}=0.78, p<0.001)$ and $\mathrm{ApN}(\mathrm{r}=0.54$, $p<0.01)$, and intestinal absorption of glucose $(\mathrm{r}=0.50, p<$ $0.01)$, leucine $(\mathrm{r}=0.70, p<0.001)$, and proline $(\mathrm{r}=0.49, p$ $<0.01)$. These parameters also correlated positively with plasma cortisol values, but the correlation coefficients were lower than those obtained when relative adrenal gland weights were used in the correlation analyses.

\section{DISCUSSION}

Growth and functional development of the GIT during the period immediately before and after birth play key roles in the transition from parenteral to enteral nutrition. During the last weeks before term, the pig intestine grew more rapidly than the body as a whole and the functional capacity increased for most digestive processes. In the pig, the most marked maturational changes occurred for stomach acidity and chymosin concentrations, pancreatic amylase and trypsin levels, intestinal lactase and ApN activity, and intestinal absorption of glucose and protein macromolecules. Reviews on the ontogeny of gastrointestinal function in man show that rapid maturational changes also take place for many gut functions in human fetuses in late gestation (34) although the exact age-related development varies widely among different GIT functions. In both man and pig (this study), the prenatal increases in GIT function occupies most of the third trimester, while in experimental animals, such as rat, rabbit and guinea pig, such increases do not occur until quite late in the last trimester (34). Generally, GIT functions start to develop earlier in gestation in man, compared with pigs and other experimental animals, despite that mature function may not reached until considerable time after birth.

After birth, enteral nutrient intake is known to stimulate further GIT growth and functional maturation, and continuation of total parenteral nutrition after birth is associated with impaired development in both pig and man (35-37). Also before birth, the provision of artificial enteral "diets," such as elemental nutrients, milk or growth factors, increases intestinal growth, uptake capacity for certain nutrients (e.g. glucose), and the activity of selected intestinal enzymes (e.g. maltaseglucoamylase, aminopeptidase A) $(2,38-40)$. It is not clear however, to which extent the natural enteral "diet" in utero plays an important maturational role in late gestation when GIT structure and function mature very rapidly. The present results suggest that esophageal obstruction at this time is associated with decreased growth of the body and particularly of the small intestine. The impact of ligation was not consistent among enterocyte functions in that enzyme activities or transport rates in ligated fetuses were higher (lactase, sucrase, DPPIV), similar to (amino acid and peptide) or lower (ApA activity and glucose transport) than those measured in sham-operated fetuses. The findings suggest that the presence or absence of fetal swallowing between 80 and $91 \%$ gestation is not crucial for gastric, pancreatic and intestinal functions. The results confirm the clinical evidence that obstruction of fetal fluid ingestion is 


\section{Sham operation Esophageal ligation}
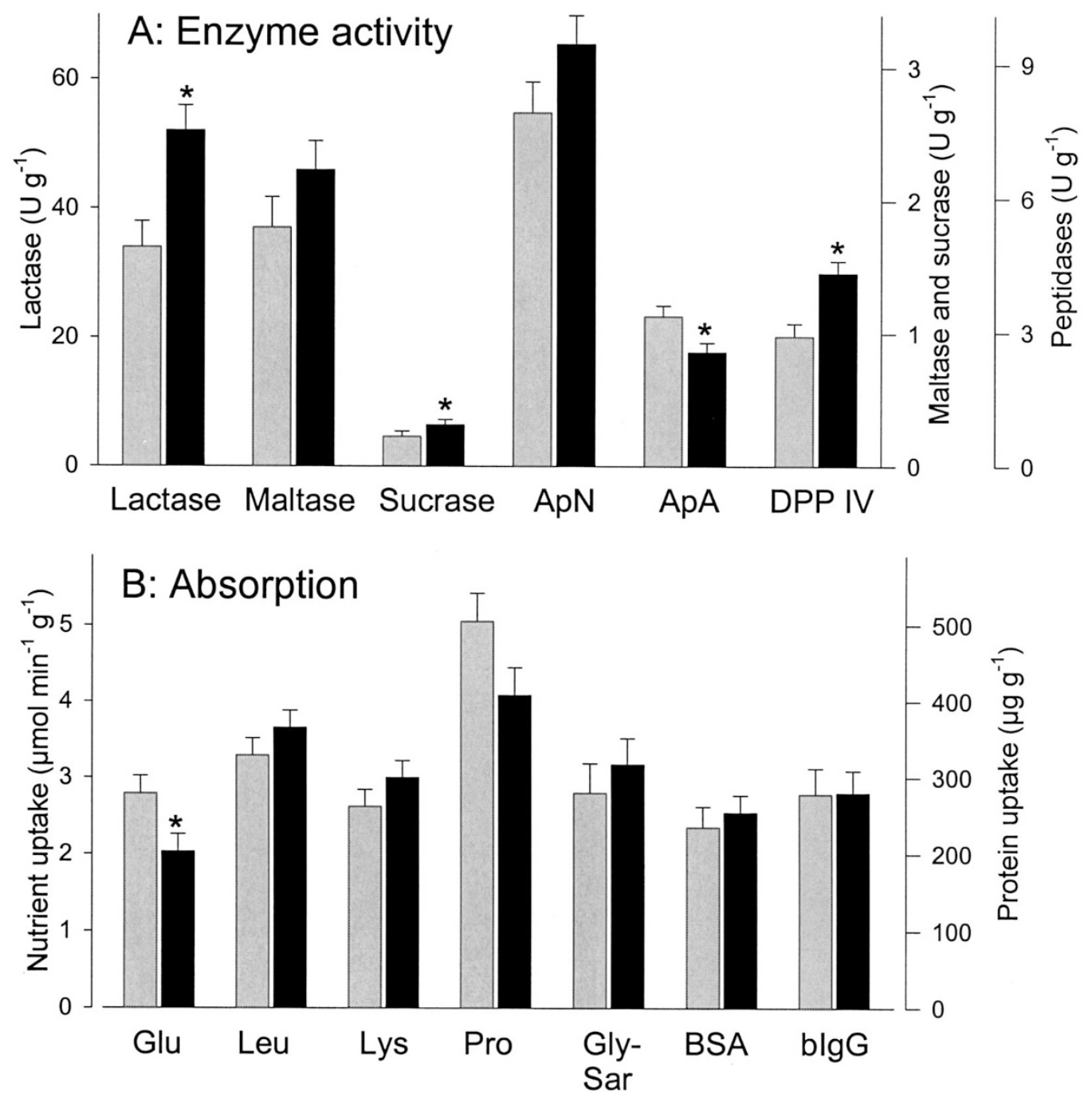

Figure 3. The effects of fetal esophageal obstruction on $(A)$ intestinal activity of 3 disaccharidases (lactase, maltase, sucrase) and 3 peptidase enzymes (ApN, ApA, DPP IV), and (B) intestinal uptake of glucose, 3 amino acids (leucine, lysine, proline), a dipeptide (glycine-sarcosine), and 2 protein macromolecules (BSA and bovine IgG). Values are LS means \pm SEM values across the 3 intestinal segments (proximal, middle, distal). See also legend to Fig. 1.

particularly detrimental for body and GIT growth during the final stages of gestation (9-11). This may lead to reduced digestive and absorptive capacity in the newborn, mainly as a result of the lowered total gut mass. This GIT growth retardation may be reversible because GIT growth can be normalized in ligated fetuses if fluid ingestion is allowed to resume (15), or if more complex enteral diets are provided in late gestation (16, 40).

Although the fetal blood gas levels at delivery were similar in ligated, sham-operated and unoperated fetuses, the ligated animals appeared emaciated and stressed, also evidenced by the rise in plasma cortisol and relative adrenal gland weight. This was expected because both the pig and many other species, show an increased adrenocortical sensitivity to ACTH during the final stage of gestation (25), and body growth rate decreases just before term (26). Although the sham-operated fetuses may have experienced a moderate degree of fetal distress, this did not result in cortisol concentrations exceeding those in similar aged controls or cause growth retardation. Despite the positive relationship between cortisol concentrations and $\mathrm{Hb}$ values in previous studies on fetal pigs (32), the hematocrit and $\mathrm{Hb}$ values were similar in ligated and shamoperated fetuses, but higher than in unoperated control pigs. The fact that the intestinal to body weight ratio was increased in sham-operated fetuses, compared with unoperated fetuses, may be related to moderate endocrine and metabolic changes associated sham fetal surgery. This hypothesis warrants further investigation.

Probably, both animals and infants that experience a GIT obstruction in late gestation are exposed to elevated cortisol levels. In this manner, the catabolic actions of cortisol may enhance the growth retardation induced by lack of swallowed fluid. In the present study, only body weight, and not intestinal weight, correlated negatively with cortisol and relative adrenal gland weight values. Consistent with studies in fetal lambs and rabbits $(14-16,41,42)$, the lack of swallowed fluid seems to be 
the main factor inducing intestinal growth retardation in pig fetuses after esophageal obstruction. The relatively short period of esophageal ligation in this study and in studies on rabbits, compared with studies on fetal lambs $(13,15)$, may explain the lack of effect on mucosal morphology after esophageal obstruction in prenatal pigs.

The normal increase in fetal glucocorticoid secretion toward term accelerates the enzymic development of the fetal stomach, pancreas and small intestine, but the effects vary among different stages of development and different GIT functions $(23,40,43)$. Correspondingly, administration of glucocorticoids before birth reduces the risk of intestinal disease in preterm infants (24). In light of these influences of cortisol, we cannot exclude the possibility that the precocial increase in cortisol in the ligated fetuses triggered an earlier maturation of some digestive functions. If so, this may have compensated for maturational delays caused by the loss of luminal fluid stimuli, and thereby reduced the magnitude of declines in digestive functions. Still, because of reduced GIT growth, the digestive capacities of ligated fetuses were not as well developed as those of the shamoperated or unoperated fetuses. In addition, cortisol effects are unlikely to have played a major role since none of the functional parameters showing a significant positive correlation with plasma cortisol or adrenal gland weight in control animals (stomach chymosin, intestinal maltase and APN activity, intestinal absorption of glucose, leucine, and proline) were elevated in ligated fetuses compared with sham-operated fetuses. Most likely, the observed increases in intestinal lactase, sucrase, and DPP IV activity in ligated fetuses result from the absence of nutrients or regulatory substances in swallowed fluid in the intestinal lumen. In addition to a general stimulation of intestinal growth, these substances may selectively affect certain brush border functions by changing enterocyte turnover and/or the biosynthetic capacity of specific proteins.

Saturable, carrier-mediated glucose transport can be detected in fetal pigs as early as $43 \%$ gestation, and throughout the remainder of gestation there is an increase in uptake, with a possible presence of multiple transporter types (44). Consistent with findings in rabbits (45), rates of glucose transport increased rapidly in late gestation, and absorption decreased after esophageal ligation. The associated reduction in glucose accumulation ratio in the present study indicates that this was coupled with a decrease in the density of carriers.

Measurements of amino acid absorption using intact tissues are complicated by passive influx. The observed kinetic constants and accumulation ratios greater than 1.0 support previous findings in that saturable transport systems for amino acids are present at $80 \%$ of gestation in pigs (44). The lack of increases in absorption of the amino acids and dipeptide by intact tissues during late gestation in both pigs and rabbits reflects two opposing developmental processes. The prenatal increases in $V_{\max } \mathrm{s}$ indicate a developmental increase in carrier density and possibly carrier type (44). Despite the increases in carrier-mediated absorption, total rates of amino acid absorption did not change notably, probably due to a decrease in permeability and a maturation of the mucosal barrier. It is uncertain if the decreased permeability was due to changes in the apical membrane of the enterocytes or the junctional complexes linking the enterocytes (i.e. the paracellular pathway). Luminal stimuli from swallowed fluid did not appear to affect these maturational changes, although it cannot be excluded that a cortisol-mediated stimulation of leucine, proline, and glucose transport have in part compensated for reduction in transport in response to esophageal ligation. Again, cortisol influences would be limited, particularly for amino acid uptakes, because these did not normally undergo a prenatal increase in parallel with plasma cortisol levels.

The newborn pig has an ability to absorb large intact proteins (e.g. immunoglobulins) by endocytosis, but this ability is lost postnatally, shortly after the intake of enteral food (4). Our results show that macromolecular absorption varies among different proteins (e.g. BSA and BIgG), increases rapidly in the prenatal period, and is not dependent on swallowed fluid for maximal endocytotic capacity. In contrast, luminal colostrum has a profound influence on the ability of the pig intestine to absorb intact proteins, both before (32) and after (4) birth.

\section{CONCLUSION}

In conclusion, this study suggests that the absence of fetal fluid swallowing for a short period in late gestation reduces overall intestinal growth, with only marginal and inconsistent effects on the tissue-specific digestive and absorptive function. Postnatally, the digestive and absorptive capacity is highly sensitive to, and is often matched with, changes in enteral dietary input $(4,30,46,47)$. Prenatally, maturation of GIT function may be more dependent on internal signals (genetic, endocrine) than on luminal stimuli (enteral nutrients and bioactive factors).

Acknowledgments. The expert technical assistance of Anna Siekierska, Merete Stubgaard, Bente Synnetsvedt, Inger Heintze, Anny Pedersen, Niels Raunkjær, Anders Andersen, and Inger Mattsson is gratefully acknowledged. Kirsten Ravn is thanked for help with the cortisol assay.

\section{REFERENCES}

1. Schwarz SM, Heird WC 1994 Effects of feeding on the small intestinal mucosa of beagle pups during the first $5 \mathrm{~d}$ of life. Am J Clin Nutr 60:879-886

2. Sangild PT, Silver M, Schmidt M, Fowden AL 1996 The perinatal pig in pediatric gastroenterology. In: Tumbleson ME, Schnook L (eds) Advances in Swine in Biomedical Research, Plenum, New York, pp 745-756

3. Zhang H, Malo C, Boyle CR, Buddington RK 1998 Diet influences development of the pig (Sus scrofa) intestine during the first 6 hours after birth. J Nutr 128:1302-1310

4. Jensen AR, Elnif J, Burrin DG, Sangild PT 2001 Development of intestinal immunoglobulin absorption and enzyme activities in neonatal pigs is diet-dependent. J Nutr $131: 3259-3265$

5. Pritchard JA 1966 Fetal swallowing and amniotic fluid volume. Obstet Gynecol 28:606-610

6. Gitlin D, Kumate J, Morales C, Noriega L, Arevalo N 1972 The turnover of amniotic fluid protein in the human conceptus. Am J Obstet Gynecol 113:632-645

7. Ross MG, Nijland MJ 1998 Development of ingestive behavior. Am J Physiol 274:R879-R893

8. Pitkin RM, Reynolds WA 1975 Fetal ingestion and metabolism of amniotic fluid protein. Am J Obstet Gynecol 123:356-363

9. Pierro A, Cozzi F, Colarossi G, Pierce AM, Lister J 1987 Does fetal gut obstruction cause hydramnios and growth retardation? J Pediatr Surg 22:454-457

10. Blakelock R, Upadhyay V, Kimble R, Pease P, Kolbe A, Harding J 1998 Is a normally functioning gastrointestinal tract necessary for normal growth in late gestation? Pediatr Surg Int 13:17-20

11. Serrano J, Zetterstrom R 1987 Disaccharidase activities and intestinal absorption in infants with congenital intestinal obstruction. J Pediatr Gastroenterol Nutr 6:238-243 
12. Mulvihill SJ, Albert A, Synn A, Fonkalsrud EW 1985 In utero supplemental fetal feeding in an animal model: effects on fetal growth and development. Surgery 98:500-505

13. Trahair JF, Harding R, Bocking AD, Silver M, Robinson PM 1986 The role of ingestion in the development of the small intestine in fetal sheep. Q J Exp Physiol 71:99-104

14. Mulvihill SJ, Stone MM, Fonkalsrud EW, Debas HT 1986 Trophic effect of amniotic fluid on fetal gastrointestinal development. J Surg Res 40:291-296

15. Trahair JF, Harding R 1995 Restitution of swallowing in the fetal sheep restores intestinal growth after midgestation esophageal obstruction. J Pediatr Gastroenterol Nutr 20:156-161

16. Trahair JF, Sangild PT 2000 Fetal organ growth in response to infusion of amniotic fluid, colostrum, milk, or gastrin-releasing peptide; a study in fetal sheep. Reprod Fertil Dev 12:87-95

17. Kimble RM, Breier BH, Gluckman PD, Harding JE 1999 Enteral IGF-I enhances fetal growth and gastrointestinal development in oesophageal ligated fetal sheep. J Endocrinol 162:227-235

18. Grand RJ, Watkins JB, Torti FM 1976 Development of the human gastrointestinal tract. A review. Gastroenterology 70:790-810

19. Sangild PT, Berghorn KA, Nathanielsz PW 2000 Precocious development of disaccharidases in the baboon intestine. Gastroenterology 118:A294

20. Simon-Assmann PM, Kedinger M, Grenier JF, Haffen K 1982 Control of brush border enzymes by dexamethasone in the fetal rat intestine cultured in vitro. J Pediatr Gastroenterol Nutr 1:257-265

21. Trahair JF, Perry RA, Silver M 1986 Studies on the maturation of the small intestine of the fetal sheep. I. The effects of bilateral adrenalectomy. Q J Exp Physiol 72:61-69

22. Buchmiller TL, Kim CS, Chopourian HL, Fonkalsrud EW 1994 Transamniotic fetal feeding: enhancement of growth in a rabbit model of intrauterine growth retardation. Surgery $116: 36-41$

23. Sangild PT, Sjostrom H, Noren O, Fowden AL, Silver M 1995 The prenata development and glucocorticoid control of brush-border hydrolases in the pig small intestine. Pediatr Res 37:207-212

24. Halac E, Halac J, Begue EF, Casanas JM, Indiveri DR, Petit JF, Figueroa MJ, Olmas JM, Rodriguez LA, Obregon RJ 1990 Prenatal and postnatal corticosteroid therapy to prevent neonatal necrotizing enterocolitis: a controlled trial. J Pediatr 117:132-138

25. Silver M, Fowden AL 1989 Pituitary-adrenocortical activity in the fetal pig in the last third of gestation. Q J Exp Physiol 74:197-206

26. Fowden AL, Szemere J, Hughes P, Gilmour RS, Forhead AJ 1996 The effects of cortisol on the growth rate of the sheep fetus during late gestation. J Endocrinol 151:97-105

27. Bloomfield FH, Knight DB, Breier BH, Harding JE 2001 Growth restriction in dexamethasone-treated preterm infants may be mediated by reduced IGF-I and IGFBP-3 plasma concentrations. Clin Endocrinol 54:235-242

28. Buddington RK, Elnif J, Puchal-Gardiner AA, Sangild PT 2001 Intestinal apica amino acid absorption during development of the pig. Am J Physiol 280:R241-R247

29. Sangild PT, Foltmann B, Cranwell PD 1991 Development of gastric proteases in fetal pigs and pigs from birth to thirty six days of age. The effect of adrenocorticotropin (ACTH). J Dev Physiol 16:229-238

30. Karasov WH, Diamond JM 1983 Adaptive regulation of sugar and amino acid transport by vertebrate intestine. Am J Physiol 245:G443-G462
31. SAS 1988 In: SAS/STAT ${ }^{\text {TM. }}$ Users Guide, 6.03 edition. SAS Institute Inc., Cary, NC, USA pp 549-640

32. Sangild PT, Trahair JF, Loftager MK, Fowden AL 1999 Intestinal macromolecule absorption in the fetal pig after infusion of colostrum in utero. Pediatr Res 45:595602

33. Silver M, Comline RS, Fowden AL 1983 Fetal and maternal endocrine changes during the induction of parturition with the PGF analogue, cloprostenol, in chronically catheterized sows and fetuses. J Dev Physiol 5:307-321

34. Grand JG, Watkins JB, Torti FM 1976 Development of the human gastrointestinal tract. A review. Gastroenterology 70:790-810

35. Dudley MA, Wykes LJ, Dudley W, Burrin, DG, Nichols BL, Rosenberger J, Jahoor F, Heird WC, Reeds PJ 1998 Parenteral nutrition selectively decreases protein synthesis in the small intestine. Am J Physiol 274:G131-G137

36. Shulman RJ, Schanler RJ, Lau C, Heitkemper M, Ou CN, Smith EO 1998 Early feeding, feeding tolerance, and lactase activity in preterm infants. J Pediatr 133:645649

37. Burrin DG, Stoll B, Jiang R, Petersen Y, Elnif J, Buddington RK, Schmidt M., Holst JJ, Hartmann B. \& Sangild PT 2000 GLP-2 stimulates intestinal growth in premature TPN-fed pigs by suppressing proteolysis and apoptosis Am J Physiol 279:1249-1256

38. Buchmiller TL, Fonkalsrud EW, Kim CS, Chopourian HL, Shaw KS, Lam MM, Diamond JM 1992 Upregulation of nutrient transport in fetal rabbit intestine by transamniotic substrate administration. J Surg Res 52:443-447

39. Buchmiller TL, Shaw KS, Chopourian HL, Lloyd KC, Gregg JP, Rivera FA Jr, Lam ML, Diamond JM, Fonkalsrud EW 1993 Effect of transamniotic administration of epidermal growth factor on fetal rabbit small intestinal nutrient transport and disaccharidase development. J Pediatr Surg 28:1239-1244

40. Sangild PT, Fowden AL, Trahair JF 2000 How does the fetal gastrointestinal tract develop in preparation for enteral nutrition after birth? Livest Prod Sci 66:141-150

41. Buchmiller TL, Gregg J, Rivera FA Jr, Diamond JM, Fonkalsrud EW 1993 Effect of esophageal ligation on the development of fetal rabbit intestinal lactase. J Pediatr Surg 28:1473-1477

42. Karnak I, Tanyel FC, Muftuoglu S, Unsal I, Cakar N, Buyukpamukcu N, Hicsonmez A 1996 Esophageal ligation: effects on the development of fetal organic systems. Eur J Pediatr Surg 6:328-333

43. Sangild PT, Hilsted L, Nexø E, Fowden AL, Silver M 1994 Secretion of acid, gastrin and cobalamin-binding proteins by the fetal pig stomach: Developmental regulation by cortisol. Exp Physiol 79:135-146

44. Buddington RK, Malo C 1996 Intestinal brush-border membrane enzyme activities and transport functions during prenatal development of pigs. J Pediatr Gastroenterol Nutr 23:51-64

45. Buchmiller TL, Shaw KS, Lam ML, Stokes R, Diamond JS, Fonkalsrud EW 1994 Effect of prenatal dexamethasone administration: fetal rabbit intestinal nutrient uptake and disaccharidase development. Surg Res 57:274-279

46. Buddington RK, Diamond JM 1989 Ontogenetic development of intestinal nutrient transporters. Annu Rev Physiol 51:601-619

47. Weiss SL, Lee EA, Diamond J 1998 Evolutionary matches of enzyme and transporter capacities to dietary substrate loads in the intestinal brush border. Proc Natl Acad Sci USA 95:2117-212 